УДК 811.133.1'04'373.21(043.5)

DOI https://doi.org/10.26661/2414-1135-2021-83-29

\title{
ФРАНЦУЗЬКІ ВЛАСНІ НАЗВИ-АНТРОПОНІМИ З ПОЗИЦІї ЗМІСТУ, ФОРМИ ТА ФУНКЦЇ̈
}

\author{
Пежинська О. М. \\ кандидат філологічних наук, доцент, \\ дочент кафедри романо-германської філології \\ Тернопільський національний педагогічний університет \\ імені Володимира Гнатюка \\ вул. Максима Кривоноса, 2, Тернопіль, Украӥна \\ orcid.org/0000-0003-4904-084X \\ opezhynska@gmail.com
}

\author{
Ключові слова: власна \\ назва, загальна назва, \\ антропонім, французька \\ мова, морфологічні \\ характеристики, мовне \\ функціонування, ономастичні \\ дослідження.
}

У статті здійснено грунтовний аналіз мовознавчих праць, присвячених французьким власним назвам-антропонімам, визначено функціональну спрямованість власних назв та їх морфологічну характеристику. Акцентовано на вагомому внеску науковців в означену проблему, змальовано перспективу подальших наукових розвідок.

Інтерес до вивчення французьких назв-антропонімів зумовлений багатьма факторами, в першу чергу протиставленням власних назв загальним, 3 яким пов’язують їх семантичні та морфологічні особливості.

Наголошено на тому, що основоположною $\epsilon$ характеристика всіх власних назв - бути індивідуальним найменуванням, що безпосередньо відбивається на природі його лексичного змісту. Визначальним фактором для встановлення значення власної назви вчені пропонують вважати контекст, оскільки власна назва володіє як мовним, так і мовленнєвим значенням.

Визначення функціональної спрямованості власної назви пов'язують перш за все з тим, що вона називає одиничні об'єкти та утворюється в результаті мовної операції, яка полягає в тому, що в якійсь ситуації відбувається виділення певного об'єкта 3 метою його називання.

Виокремлено кілька поглядів, що стосується природи лексичного змісту власної назви: власна назва - як семантично порожній знак, відсутність лексичного значення, i, навпаки, власна назва володіє як мовним, так i мовленнєвим значенням.

Описуючи категорію числа, для прізвищ часто застосовується флексія -s, зокрема для прізвищ знатних родин, в іншому випадку для підкреслення унікальності - флексія відсутня.

Наголошено на тому, що категорія детермінації іменників визнається не всіма вченими, проте всі дослідники впевнені в тому, що власні імена-антропоніми не потребують детермінації, оскільки вже в мові детерміновані та визначені.

Відсутність чітко визначеного синтаксичного статусу опозиції назва загальна/власна дає змогу багатьом дослідникам говорити про перехід власних назв у розряд загальних. 


\title{
FRENCH PROPER NAMES-ANTHROPONYMS FROM THE CONTENT, FORM, AND FUNCTIONS POINTS OF VIEW
}

\author{
Pezhynska O. M. \\ Candidate of Philological Sciences, Associate Professor, \\ Associate Professor at the Department of Romano-Germanic philology \\ Ternopil Volodymyr Hnatiuk National Pedagogical University \\ Maxyma Kryvonosa str., 2, Ternopil, Ukraine \\ orcid.org/0000-0003-4904-084X \\ opezhynska@gmail.com
}

Key words: proper name, common name, anthroponym, French language, morphological characteristics, language functioning, onomastic research.
The article gives a deep analysis of linguistic researches on French proper names-anthroponyms, the functional orientation of proper names, and their morphological characteristics. It has been emphasized on the significant contribution of scientists to this problem. The prospects for further scientific research has been also described.

The interest in the study of French names-anthroponyms is caused by the opposition of proper names to the general ones, with which their semantic and morphological features are connected.

It is mentioned that the fundamental characteristic of all proper names is to be an individual name, which affects the nature of its lexical content directly. Scientists propose to consider the context as a determining factor for establishing the meaning of a proper name because a proper name has both linguistic and speech meaning.

Determining the functional orientation of a proper name is primarily associated with the fact that it names individual objects and is formed as a result of a language operation, where the selection of a particular object in some situations is made in order to name it.

There are several points of view concerning the nature of the lexical meaning of a proper name: proper name as a semantically empty sign, lack of lexical meaning, and vice versa. Proper name has both linguistic and speech meaning. Describing the category of number, the inflection -s is often used for surnames, for surnames of noble families; in particular, otherwise, to emphasize uniqueness inflection is absent.

It has been emphasized also that the category of determination of nouns is not recognized by all scholars, but all researchers are convinced that proper anthroponyms do not need determination because they are determined and defined in the language already.

The lack of a clearly defined syntactic status of the common/proper name opposition allows talking about the transition of proper names into the category of common.
Постановка проблеми. Серед усіх власних назв французької мови найбільший інтерес викликають дві найбільші групи: топоніми i антропоніми. Дослідження обох груп власних назв (топонімів та антропонімів) у французькій мові $з$ погляду парадигматики і синтагматики становило б собою дуже складне завдання, по-перше, через обсяг матеріалу, по-друге, через його різнорідність. Для безпосереднього вивчення парадигматичних i синтагматичних характеристик французьких антропонімів необхідно зрозуміти, яке місце останні займають у класі іменників i як вони відповідають частині мови «іменник» із позиції змісту, форми та функції.

Загальні відомості про французькі власні назви-антропоніми містяться в теоретичних і практичних роботах із граматики французької мови [1-4].

Особливий інтерес вчених становить функціонування власної назви, оскільки, незважаючи на нормативне вживання французьких антропонімів без артикля, аналіз текстів та усного мовлення показує, що вживання артиклів 3 антропонімами відбувається досить часто [5-8]. 
Метою нашої розвідки є аналіз мовознавчих праць, присвячених французьким антропонімам та визначення їх місця у складі частини мови «іменник» із позиції змісту, форми та функції. 3 метою реалізації поставленої мети передбачається вирішення таких завдань: визначення функціональної спрямованості власних назв та ix морфологічних характеристик, можливостей мовного функціонування власних назв; проаналізувати співвідношення загальної назви з власною з погляду морфології; розглянути вживання власних назв із детермінативами.

Об'єктом дослідження є французькі власні назви-антропоніми. Предметом дослідження $\epsilon$ французькі власні назви-антропоніми 3 позиції змісту, форми та функції.

Виклад основного матеріалу дослідження. Поділ іменників на загальні і власні здійснюється зазвичай на підставі логіко-семантичного критерію: власні назви служать для іменування одиничних об'єктів дійсності, в той час як загальні назви називають цілі класи об'єктів. У всіх семантичних класифікаціях іменників поділ іменників на загальні і власні є основоположним, оскільки «висловлює два взаємопротилежних і взаємодоповнюючих процесів у мисленні, сприйнятті світу і мови: індивідуалізацію та узагальнення» $[9$, c. 91$]$.

У спеціальних ономастичних дослідженнях визначення власної назви пов'язують перш за все 3 тим, що вона називає одиничні об'єкти. Так, А.В. Суперанська вважає основним у власних назвах «...їхнє особливе положення у мові, застосованість до індивідуальних обєктів, що вирізняються із ряду подібних, вживання назв в особливих, окремих значеннях при відсутності у них загального значення» [9, с. 46].

Н.Д. Арутюнова говорить про власну назву як про ту, яка в значається властивістю унікальної референції [10, с. 2].

Власна назва утворюється в результаті мовної операції, яка полягає в тому, що в якійсь ситуації відбувається виділення певного об'єкта 3 метою його називання, що належить йому і тільки йому. Так, топонім Toulouse належить не до всіх міст, а лише до одного, унікального, що виражається у своїй індивідуальності. Основоположна характеристика всіх власних назв - бути індивідуальним найменуванням, що безпосередньо відбивається на природі його лексичного змісту.

Стосовно природи лексичного змісту власної назви не існує єдиної думки: в теоретичній літературі представлені кілька поглядів. Власна назва розглядається як семантично порожній знак $[9$, с. $55 ; 11 ; 12]$.

Деякі лінгвісти стверджують, що у власної назви відсутнє значення і вона неспроможна вира- жати лексичне поняття. Так, датський лінгвіст В. Брендаль вважає, що понятійність власної назви наближається до нуля, і на цій підставі визначає іiі як знак неописаного об'єкта, тобто як знак, який називає, але не описує [13, с. 91]. А.А. Реформатський вважає: «Загальна властивість всіх власних назв полягає в тому, що вони $<\ldots>$ ніяких понять не висловлюють. Власні назви гіпертрофовано номінативні» [14, с. 176]. Як розпізнавальний, що не має лексичного значення, мовний знак, власна назва представлена в роботах Ж. Вандріеса [15, с. 179], А.А. Уфімцевої [16, с. 72-73], Ю.С. Степанова [17, с. 12].

Французький лінгвіст М. Бреаль стверджував, що істотної різниці між значенням власної назви і загальної немає, і тим самим практично викреслював границі між цими класами [18]. Прихильники концепції «великого значення» власної назви аналізують не мовне, а мовленнєве значення назви. Визначальним фактором для встановлення значення власної назви вони пропонують вважати контекст. Детальну розробку та кінцеве оформлення ця теорія отримала у працях О. Есперсена [19].

Прихильники мовно-мовленнєвого подходу до власної назви [20; 21] стверджують, що власна назва володіє як мовним, так і мовленнєвим значенням. С.Д. Кацнельсон уподібнює власну i загальну назви та зазначає, що «всі слова як одиниці мовної системи виражають дещо спільне. Навіть і власні назви, які часто згадуються в цьому зв'язку як виняток, містять елемент узагальнення.

Морфологічні характеристики власної назви завжди привертали до себе увагу дослідників. У традиційній граматиці власна назва розглядається зазвичай як виняток, яка має особливості в морфологічному оформленні. Так, наприклад, у граматиці Р. Вагнера та Ж. Пеншон [4] у розділі, присвяченому іменнику, зазначається, що іменники поділяються а) за походженням б) за структурою, в) за екстенсією. Саме до останньої групи належать власні назви. Далі зазначається, що для всіх без винятку іменників є справедливим визначення: іменники - це слова, по-перше, які характеризуються категоріями роду і числа, i по-друге, спираються на специфічні детермінативи (артиклі, присвійні та вказівні прикметники). У процесі перегляду категорії роду власні назви знаходяться після неологізмів і особливих словотвірних випадків серед іменників.

У процесі розгляду формальні показники роду (закінчення та суфікси) як приклади наводяться виключно загальні іменники. Категорія числа власних назв розглядається в параграфі про значення категорії числа, де згадуються тільки прізвища і наводяться такі приклади: un Moliere, les Moliere (s), les Bourbons, les Stuarts. 
Автори вказують на правила вживання або невживання кінцевої - $s$, але про значення самої категорії у власних назв не говорять.

Суперечливість положення французьких власних назв (приналежність до іменників, незважаючи на морфологічні особливості) відображається в граматиці В.Г. Гака. Іменник визначається як «слово, що позначає предмет, що володіє категорією роду і числа, здатний поєднуватися 3 детермінативами або означеннями, виконуючи функцію підмета, додатка, іменної частини присудка, прикладки». Проте дещо пізніше автор зазначає, що «в силу одиничності власні назви не володіють всіма характеристиками, властивими загальним назвам, що проявляється в особливостях вживання артикля, категорії числа, в обмеженій можливості поєднувати 3 ними означення та ін. 3 огляду на це власні назви належать до периферійних підкласів іменників» [2, с. 116-120].

У граматиці М. Гревіса «Le bon usage» [22] особливе положення власної назви не підкреслюється: так, у прикладах про вираження категорії роду іменників у низці загальних іменників наводяться приклади з антропонімами. Особливості власних назв висвітлюються тільки в розділі про категорію числа. У цій граматиці здійснюється спроба перелічити всі випадки вживання або невживання кінцевої -s у прізвищах [22, с. 229].

Проблема опису власної назви у французьких граматиках пов'язана, на наш погляд, із тим, що французькі антропоніми традиційно описуються загалом, тому зазвичай трактуються як іменники. Отже, твердження про те, що прізвище не має роду, здається необгрунтованим, оскільки рід $\epsilon$ невід'ємною категорією класу іменників.

Слідом за М.-Н. Гарі-Пріер [5, с. 5], зазначаємо деяку непослідовність у розгляді власних назв y теоретичних граматиках. Зокрема, в процесі вибору назв дослідники то протиставляють власні назви всьому класу іменників, то розглядають їх разом $з$ іншими периферійними групами іменників, тобто з тими групами, які ніби «вибиваються 3 норми» за лексичним, чи за морфологічним критерієм. Щодо цього твердження власні назви, як і неологізми та складні іменники, являють собою особливі випадки.

Розглянемо докладніше, як співвідноситься загальна назва $з$ власною з погляду морфології.

Дослідження стародавніх станів індоєвропейських мов показують, що в мові спочатку протиставлялися іменники на означення істот (активні) і неживі (пасивні). Цьому протиставленню відповідає латинська парадигма прикметників із двох членів: fortis $(m, f)$-forte $(n)$, яка $є$ давнішою, ніж парадигма bonus (m) - bona (f) - bonum (m).

Іншими словами, в мові протиставляються не чоловічий і жіночий рід, а поняття активності і пасивності. Граматична категорія роду розподіляла іменники на ті, які здатні виконувати функцію суб'єкта, і ті, що виконують роль об'єкта. Для того, щоб підкреслити це значення, Р. Лафон запропонував для позначення граматичного роду терміни l'actantiel (актантний) - для позначення суб'єкта, граматичний рід якого може бути пояснений більшою чи меншою активністю, і l'inactantiel (неактантний) - для позначення об'єкта, граматичний рід якого може бути пояснений ідеєю пасивності [23, с. 120].

Той факт, що серед давньофранцузьких неживих іменників $є$ цілі лексичні групи чоловічого (наприклад, назви дерев) або жіночого роду (наприклад, назви плодів, назви хвороб), тільки підтверджує те, що в основу семантичного протиставлення істинного роду покладений не принцип статевих відмінностей, а ступінь активності. Так, у період становлення французької мови іiі носії сприймали назви дерев як активні іменники, i тому вони стали іменниками чоловічого роду (на відміну від латинських іменників), а назви плодів як менш активних отримували значення жіночого роду.

Опис категорії числа у французьких антропонімах вимагає особливого підходу, оскільки, на відміну від загальних іменників, власні назви не мають закінчення $-s$ у множині.

Категоріальне значення числа може розглядатися як формальне протиставлення нульова флексія $/-s$, в якому відсутність флексії $-s$ означає одиничність, а присутність $-s-$ безліч предметів. Такий підхід представлений в А.К. Васильєвої [1], В.Г. Гака [2], Ж. Дюбуа [24].

Як справедливо зауважує Л.М. Скреліна [3, с. 61], такий підхід стикається 3 низкою «винятків»: збірні іменники, форма і значення яких суперечать визначенню категорії; абстрактні і предметні іменники, які за своєю природою не мають форм множини; іменники pluralia tantum, які не мають форм однини.

У разі формального підходу до категорії роду до цього списку «винятків» потрапляють і власні назви, оскільки вони не мають у множині закінчення $-s$. Інший підхід до категорії числа віддає першість не формі, а значенню категорії числа. Основне місце при такому підході відводиться множині [25; 26]. Л.М. Скреліна нагадує, що без поняття «багато» немає поняття числа [3, с. 62]. В. Виноградов зазначав, що категорія множини «виступає як міцна, повнозначна категорія» [27, с. 124].

Г. Гійом називав множину числом, а однину не-числом, виділяючи при цьому внутрішню і зовнішню множину [26, с. 204].

«Внутрішня множинність редукується в одиничність поступово, проходячи етапи «четвірковості», «трійковості», «двійковості»: pluriel 
naturel (universel) $\rightarrow$... quatriel $\rightarrow$ triel $\rightarrow$ duel $\rightarrow$ un (singulier). У quatriel (четвірковість) мається на увазі четвірка, в triel - трійка, в duel - двійка, нарешті, вивільняється одиниця» [28].

Граматична категорія числа має справу із зовнішньою множинністю, тобто множинністю арифметичною. Слова le feuillage i des feuilles виражають одне i те ж, але по-різному: у першому випадку множинність внутрішня, а в другому - зовнішня, оформлена граматично. Внутрішня множинність спрямована до одиниці, а зовнішня - від неї, «тому у кінетичної однини є тенденція до вираження недискретності (continu), а у кінетичної множини - до вираження дискретності (discontinu)» [3, с. 62].

Але перш за все розглянемо традиційне пояснення категорії числа в застосуванні до власних назв. У процесі опису категорії числа приклади традиційно наводяться тільки для прізвищ, оскільки вони в деяких випадках можуть мати закінчення $-s$ у множині. Формальне вираження категорії числа за допомогою флексії $-S$ в сучасній французькій мові можливе тільки для прізвищ знатних родин: Les Bourbons, але Les Martin.

Серед пояснень вживання або невживання $-S$ множини найпоширенішим $\epsilon$ те, що представлено у Гревіса [22, с. 299]. У його класичній граматиці зазначено, що $-s$ у множині не ставиться, коли імена позначають не цілі сім’ї, а конкретних

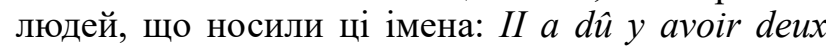
Dupont Gaston à la 8 e compagnie. Тим не менш граматика «Bon Usage» розмежовує вживання $3-s$ і без $-s$, не завжди пояснюючи саме правило.

Дослідники Ш. Бюсьер і Р. Руа [29] критикують деяку розмитість цього правила в класичній французькій граматиці і представляють чіткіше трактування вживання або невживання $-s$ у множині.

Французькі особові імена не узгоджуються 3 числом, оскільки у французькій мові підкреслюється в особовому імені індивідуальність, тобто той факт, що власне ім'я називає тільки одну людину. У реченні Il a y trois Hélène dans notre classe ім'я Hélène вживається в однині, тому що, незважаючи на те, що дівчаток, які носять це ім'я, три, кожній із них ім'я належить персонально і називає іiі і тільки іiі [29].

Французькі прізвища, як і особові імена, не узгоджуються 3 числом, наприклад, Les Chirac ont leurs rites, leurs joies, mais aussi leurs douleurs intimes et leurs angoisses cachées (L'Express 2005).

Прізвище не вживається 3 -s у множині, оскільки в цьому разі підкреслюється унікальність кожного члена сім’ї Chirac.

А при згадці знатних родин може з'являтися кінцеве $-s$ у множині, як зазначають вчені, здійснюється референція на всю династію, а не на конкретних іiі представників: Les Bonapartes, les Habsbourgs.
Категорія детермінації (визначеності/невизначеності) іменників визнається не всіма вченими, проте всі дослідники впевнені в тому, що власні імена-антропоніми не потребують детермінації, оскільки вже в мові детерміновані та визначені. Традиційні граматики вважають нормативним вживання французького власного імені-антропоніма без артикля у всіх синтаксичних функціях: підмета, додатка, іменної частини присудка. Здатність бути іменною синтагмою без артикля (або іншого детермінатива) $є$ головною особливістю функціонування власної назви.

Як показують дослідження зарубіжних лінгвістів [5; 6; 8], вживання власної назви з детермінативом не завжди означає його однозначний перехід до класу загальних назв на рівні мови. Наприклад, Tu y penses encore à cette Murielle. M.-H. Гарі-Пріер стверджує, що це речення еквівалентне реченню, де власне ім'я вжито без вказівного займенника $[5$, c. 48$]$.

Ah! C'est bien un Dupont. - Н. Фло інтерпретує це вживання як характеристику мовного об'єкта $[6$, c. 30$]$.

Ce Hugo de notre siècle. - К. Жонассон зазначає метафоричне вживання [7, с. 71].

Проблема «ненормативного», модифікованого, вживання французького власного імені (з детермінативом) розглядається вченими в рамках інтерпретації: Devrais-je ajouter même, à ce propos, qu'après la scène à laquelle j'avais assisté du haut de ma fenêtre entre Rouletabille et Matilde je $m$ 'attendais à voir celle-ci plus atterrée... quasi anéantie par cette vision menaçante d'un Larsan surgi sur eau [30, c. 123].

Ми можемо зробити висновок, що йдеться про конкретний факт, подію, яка дійсно відбулася. Ім'я Larsan не перейшло в загальне, воно $\epsilon$ референтним носію імені. М.-Н. Гарі-Пріер називає таке вживання модальним. Артикль можливий, тому що після імені є синтагма: surgi sur eau. Вчений стверджує, що такі конструкції описують певний дискурсивний образ людини, про яку йдеться, інакше кажучи, образ, обмежений тимчасовими і модальними рамками [5]. Романіст М.П. Миколаїв також досліджував вживання власних назв із детермінативами. У своїй роботі він робить припущення про наявність у французькій мові категорії прагматичної детермінації імені. Поява детермінатива викликана потребою реалізувати зміщену референцію власної назви, зміщення відбувається від ідентифікації до характеристики [31]. Вчений аналізує приклади вживання французьких антропонімів 3 артиклями і вказівними займенниками. У роботі диференціюється прагматичний ефект, який досягається в процесі вживання того чи іншого детермінатива. 
Відсутність чітко визначеного синтаксичного статусу опозиції назва загальна / назва власна дозволяє багатьом дослідникам говорити про перехід власних назв у розряд загальних. Отже, на думку деяких лінгвістів (таких, як М. Гревіс [22], О. Єсперсен [19]), у французькій мові не існує чіткої межі між власною назвою і загальною.

Висновки і перспективи подальших розробок.

У більшості проаналізованих нами робіт, що стосуються вживання власної назви 3 детермінативом, пропонується інтерпретація подібного вживання, тобто аналіз мовних значень артикульованих власних назв-антропонімів, але не його пояснення. Однією $з$ цілей цього дослідження $\epsilon$ пояснення можливостей мовного функціонування французьких назв-антропонімів за допомогою звернення до їх мовного статусу, як наприклад, механізм дії артикля, який у французькій мові $\epsilon$ показником зміни семантичного обсягу іменника.

Вчені одностайні у визначенні функціональної спрямованості власних назв - називати одиничні об'єкти. Однак ця властивість власної назви породжує суперечки 3 приводу семантичного наповнення власної назви-антропоніма. Дослідники дотримуються таких точок зору:

- власна назва не володіє мовним значенням і $\epsilon$ порожнім знаком, «етикеткою»;

- власна назва володіє асоціативною семантикою;

- власна назва має мовне значення, і цим значенням є ідентифікуюча дескрипція референта. Представники цієї течії спираються на мовно-мовленнєвий підхід до проблеми і стверджують, що в мовленні власна назва реалізує потенційно закладену вже в мові семантику.

У психосистематиці власна назва розглядається як асемантема, але це не означає відсутність значення. Цей термін описує мовну природу власної назви, нездатної до екстенсії в мовленні, яка у французькій мові експлікована в артиклі.

Вираз категорії числа пов'язаний у власних іменах-антропонімах $з$ їх асемантичністю: в процесі актуалізації в мові асемантема не може бути узагальнена, оскільки не $є$ поняттям. Неможливість узагальнення зумовлює неможливість зведення власних імен-антропонімів «до спільного знаменника», а значить, і вживання їх у множині.

Будучи асемантемою, власна назва-антропонім не потребує артикля під час актуалізації, оскільки останній вказує на обсяг актуалізованого поняття, яким власна назва-антропонім не володіє.

Подальші наукові розвідки будуть спрямовані на конкретизацію та ретельне вивчення функціональних характеристик французьких власних назв-антропонімів у сучасній публіцистиці, оскільки останні не перебували у фокусі досліджень вітчизняних лінгвістів.

\section{ЛІТЕРАТУРА}

1. Васильева Н.М., Пицкова Л.П. Французский язык: теоретическая грамматика. Морфология. Синтаксис: ускоренный курс : (на фр. яз.) : учеб. для ин-тов и фак. иностр. яз. Москва : Высш. шк., 1991. 298 с.

2. Гак В.Г. Теоретическая грамматика французского языка : учеб. для вузов. Москва : Добросвет, 2000. 832 с.

3. Скрелина Л.М. Лекции по теоретической грамматике французского языка : учеб. пособие. В 2 ч. Ч. І. Санкт-Петербург : Златоуст, 1997. 95 c.

4. Wagner R.L., Pinchon J. Grammaire du francais classique et moderne. Paris : Librairie Hachette, 1974. $648 \mathrm{p}$.

5. Gary-Prieur M-N. Le nom propre constitue-t-il une categorie linguistique? Langue française. 1991. № 92. P. 4-25.

6. Flaux N. L'antonomase du nom propre ou la memoire du referent. Langue francaise. 1991. № 92. P. 26-45.

7. Jonasson K. Les noms propres metaphoriques : construction et interpretation. Langue française. 1991. № 92. P. 64-80.

8. Kleiber G. Du nom propre non modifie au nom propre modifie : le cas de la determination des noms propres par I'adjectif demonstratif. Langue francaise. 1991. № 92. P. 82-103.

9. Суперанская А.В. Общая теория имени собственного. Москва : Наука, 1973. 366 с.

10. Арутюнова Н.Д. Язык и мир человека. 2-е изд., испр. Москва : Языки русской культуры, 1999. 895 с.

11. Molino J. Le nom propre dans la langue. Langages. 1982. № 66. P. 5-21.

12. Togeby K. Structure immanente de la langue francaise. Copenhague : Nordisk Sprog-og Kulturforlag, 1951. 282 p.

13. Brondal V. Les parties du discours : partes orationis : etudes sur les categiries linguistiques. Copenhagen: Munks-gaard, 1948. 203 p.

14. Реформатский А.А. Введение в языковедение : учебник для студентов филол. педагог. учеб. заведений. 5-е изд., уточнен. Москва : Аспект Пресс, 2003. 536 с.

15. Вандриес Ж. Язык. Лингвистическое введение в историю / пер. с фр. под ред. и с предисл. Р.О. Шор; примеч. П.С. Кузнецова. Москва : Соцэкгиз, 1937. $410 \mathrm{c}$.

16. Уфимцева А.А. Типы словесных знаков. Москва : Наука, 1974. 156 с.

17. Степанов Ю.С. Основы общего языкознания : учеб. пособие. Изд. 2-е, перераб. Москва : Просвещение, 1975. $271 \mathrm{c}$.

18. Breal M. Essai de semantique : science des significations. Paris : Larousse, 1924. 235 p. 
19. Есперсен О. Философия грамматики / пер. с англ. В.В. Пассека и С.П. Сафроновой ; под ред. и с пре-дисл. Б.А. Ильиша. 2-е изд., стер. Москва : Едиториал УРСС, 2002. 408 с. (Лингвистическое наследие XX века).

20. Кацнельсон С.Д. Содержание слова, значение и обозначение. Ленинград : Наука, Ленингр. отд-ние, 1965.109 с.

21. Никонов В.А. Имя и общество. Москва : Наука, 1974. 278 c.

22. Grevisse M. Le bon usage. 13 ed. Paris : Duculot, 1994. $1762 \mathrm{p}$.

23. Lafont R. Genre et nombre en indo-europeen : essai d'explication unitaire des pertinences du nominal. Revue des Langues romanes. 1970. T. 79, № 1. P. 89-148.

24. Dubois J. Grammaire structural du francais : nom et pronom. Paris : Librairie Larousse, 1965. $192 \mathrm{p}$.

25. Басманова А.Г. Именные грамматические категории в современном французском языке : учеб. пособие. Москва : Высш. шк., 1977. $198 \mathrm{c}$.

26. Guillaume G. Lecons de linguistique de Gustave Guillaume (1944-1945) Publiées sous la dir. de R. Valin, W. Hirtle et A. Joly. Quebec : Les Presses de l'Université Laval; Lille : Presses universitaires de Lille, 1991. Vol. 11. 297 p.

27. Виноградов В. В. Стилистика : теория поэтической речи. Москва : Поэтика, 1963. 255 с.

28. Скрелина Л.М. Лингвистика XX века : школа Гийома (психосистематика) : учеб. пособие к курсу «История лингвистических учений и методов анализа» [Рукопись]. Санкт-Петербург : 2002. 425 c.

29. Bussiere Ch., Roy R.-Cl. La regie d'accord en nombre des noms propres. Les actes du Colloque sur la problematique de l'amenagement linguistique enjeux et pratiques (5-7 mai 1993, l'Universite du Quebec à Chicoutimi). Montreal; Chicoutimi : Office de la langue francaise, 1994. P. 3-13.

30. Leroux G. Le parfum de la dame en noir. Paris : Le livre de poche, $1960.448 \mathrm{p}$.

31. Николаев Н.П. Прагматическая значимость имени собственного лица с детерминативом в современном французском языке : автореф. дис. ... канд. филол. наук : 10.02.05. Минск, гос. пед. ин-т иностр. яз. Минск, 1996. $17 \mathrm{c}$.

\section{REFERENCES}

1. Vasil'eva N.M., Pickova L.P. (1991) French language: a theoretical grammar. Morphology. Syntax [Francuzskij yazyk: teoreticheskaya grammatika. Morfologiya. Sintaksis]. M. : Vysshaya shkola [in Russian].
2. Gak V.G. (2000) Theoretical grammar of the French language [Teoreticheskaya grammatika francuzskogo yazyka]. M. : Dobrosvet [in Russian].

3. Skrelina L.M. (1997) Lectures on Theoretical French Grammar [Lekcii po teoreticheskoj grammatike francuzskogo yazyka]. $\mathrm{SPb}$. Zlatoust [in Russian].

4. Wagner R.L., Pinchon J. (1974) Grammaire du francais classique et moderne. Paris : Librairie Hachette, $648 \mathrm{p}$.

5. Gary-Prieur M-N. (1991) Le nom propre constitue-t-il une categorie linguistique? Langue française. № 92. P. 4-25.

6. Flaux N. (1991) L'antonomase du nom propre ou la memoire du referent. Langue francaise. № 92. P. 26-45.

7. Jonasson K. (1991) Les noms propres metaphoriques : construction et interpretation. Langue française. № 92. P. 64-80.

8. Kleiber G. (1991) Du nom propre non modifie au nom propre modifie : le cas de la determination des noms propres par I'adjectif demonstratif. Langue francaise. № 92. P. 82-103.

9. Superanskaya A.V. (1973) General theory of proper names [Obshchaya teoriya imeni sobstvennogo]. M.: Nauka [in Russian].

10. Arutyunova N.D. (1999) The language and the world of man [Yazyk i mir cheloveka]. M. : Yazyki russkoj kul'tury [in Russian].

11. Molino J. (1982) Le nom propre dans la langue. Langages. № 66. P. 5-21.

12. Togeby K. (1951) Structure immanente de la langue francaise. Copenhague: Nordisk Sprog-og Kulturforlag, $282 \mathrm{p}$.

13. Brondal V. (1948) Les parties du discours : partes orationis : etudes sur les categiries linguistiques. Copenhagen: Munks-gaard, $203 \mathrm{p}$.

14. Reformatskij A.A. (2003) Introduction to linguistics [Vvedenie $\mathrm{v}$ yazykovedenie]. M. : Aspekt Press [in Russian].

15. Vandries Z.H. (1937) Language. Linguistic introduction to history [Yazyk. Lingvisticheskoe vvedenie v istoriyu]. M. : Socekgiz [in Russian].

16. Ufimceva A.A. (1974) Types of word marks [Tipy slovesnyh znakov]. M. : Nauka [in Russian].

17. Stepanov YU.S. (1975) Foundations of General Linguistics [Osnovy obshchego yazykoznaniya]. M.: Prosveshchenie [in Russian].

18. Breal M. (1924) Essai de semantique : science des significations. Paris : Larousse, $235 \mathrm{p}$.

19. Espersen O. (2002) Philosophy of grammar [Filosofiya grammatiki]. M.: Editorial URSS [in Russian].

20. Kacnel'son S. D. (1965) Content of the word, meaning and designation [Soderzhanie slova, znachenie i oboznachenie]. L. : Nauka [in Russian]. 
21. Nikonov V.A. (1974) Name and Society [Imya i obshchestvo]. M. : Nauka [in Russian].

22. Grevisse M. (1994) Le bon usage. 13 ed. Paris : Duculot, $1762 \mathrm{p}$.

23. Lafont R. (1970) Genre et nombre en indoeuropeen : essai d'explication unitaire des pertinences du nominal. Revue des Langues romanes. T. 79, № 1. P. 89-148.

24. Dubois J. (1965) Grammaire structural du français : nom et pronom. Paris : Librairie Larousse, 192 p.

25. Basmanova A.G. (1977) Nominal grammatical categories in modern French [Imennye grammaticheskie kategorii $\mathrm{v}$ sovremennom francuzskom yazyke]. M. : Vyssh. shk. [in Russian].

26. Guillaume G. (1991) Lecons de linguistique de Gustave Guillaume (1944-1945) Publiées sous la dir. de R. Valin, W. Hirtle et A. Joly. Quebec : Les Presses de l'Université Laval; Lille : Presses universitaires de Lille, Vol. 11. 297 p.

27. Vinogradov V.V. (1963) Stylistics: theory of poetic speech [Stilistika : teoriya poeticheskoj rechi]. M. : Poetika [in Russian].
28. Skrelina L.M. (2002) Linguistics of the XX century: Guillaume's school (psychosystematics) [Lingvistika XX veka : shkola Gijoma (psihosistematika)] : ucheb. posobie $\mathrm{k}$ kursu «Istoriya lingvisticheskih uchenij i metodov analiza». SPb. [in Russian].

29. Bussiere Ch., Roy R.-Cl. (1994) La regie d'accord en nombre des noms propres. Les actes du Colloque sur la pro-blematique de l'amenagement linguistique enjeux et pratiques (5-7 mai 1993, l'Universite du Quebec a Chicoutimi). Montreal; Chicoutimi : Office de la langue francaise, P. 3-13.

30. Leroux G. (1960) Le parfum de la dame en noir. Paris : Le livre de poche, $448 \mathrm{p}$.

31. Nikolaev N.P. (1996) The pragmatic significance of a personal name with a determinant in modern French [Pragmaticheskaya znachimost' imeni sobstvennogo lica $\mathrm{s}$ determinativom $\mathrm{v}$ sovremennom francuzskom yazyke]. (Extended abstract of Candidate's thesis). Minsk [in Russian]. 